therefore fairly readily recognisable, it is logical to assume that the monophasic spindle cell variant of synovial sarcoma might also present at this site and, given that such tumours often have a haemangiopericytoma-like pattern, problems in differential diagnosis might arise. Orbital haemangiopericytoma, ${ }^{6}$ which in most cases is less aggressive than synovial sarcoma, is best distinguished by its lack of EMA expression and also, less reliably, by its composition of more patternless, rounded, undifferentiated cells rather than a fascicular spindle cell appearance. Deep fibrous histiocytoma, ${ }^{7}$ well recognised in the orbit, ${ }^{8}$ is often pericytomalike, is usually only locally aggressive, and may be distinguished by its greater cytological polymorphism, a storiform architecture and EMA negativity. Overtly malignant cases show pronounced pleomorphism. Finally, infantile fibrosarcoma of the orbit ${ }^{9}$ may be both fascicular and pericytoma-like and does not usually metastasise. It can be distinguished from monophasic synovial sarcoma by its very early age of onset, EMA negativity, and by electron microscopic examination if necessary.

\section{Addendum}

Since submission of this manuscript, we have encountered a second example of primary orbital synovial sarcoma, presenting in a 42 year old Sri Lankan woman with an eight month history of left-sided orbital swelling. In this tumour, measuring about $2 \mathrm{~cm}$, which was adherent to the tendon sheath of the superior oblique muscle, the epithelial/glandular component was much less conspicuous but there was convincing EMA and keratin positivity. Such rapid identification of a second case, while possibly fortuitous, suggests that synovial sarcoma of the orbit may be underrecognised and perhaps more often misdiagnosed as haemangiopericytoma or fibrosarcoma than is commonly thought.

CDMF is a Cancer Research Campaign senior clinical research fellow.

1 Shields JA, Bakewell B, Augsburger JJ, Flanagan JC. Classification and incidence of space-occupying lesions of the orbit. A survey of 645 biopsies. Arch Ophthalmol 1984;102:1606-11.

2 Maurer HM, Beltangady M, Gehan EA, et al. The Intergroup Rhabdomyosarcoma study-1. A final report. Cancer 1988;61:209-20.

3 Roth JA, Enzinger FM, Tannenbaum M. Synovial sarcoma of the neck: a follow-up study of 24 cases. Cancer 1975;35:1243-53.

4 Shmookler BM, Enzinger FM, Brannon RB. Orofacial synovial sarcoma. A clinicopathologic study of 11 cases and review of the literature. Cancer 1982;50:269-76.

5 Fletcher CDM, McKee PH. Pathobiology of soft tissue tumours. Edinburgh: Churchill Livingstone, 1990.

6 Croxatto JO, Font RL. Hemangiopericytoma of the orbit: a clinicopathologic study of 30 cases. Hum Pathol 1982; 13:210-8.

7 Fletcher CDM. Benign fibrous histiocytoma of subcutaneous and deep soft tissue: a clinicopathologic analysis of 21 cases. Am J Surg Pathol 1990;14:801-9.

8 Font RL, Hidayat AA. Fibrous histiocytoma of the orbit. A clinicopathologic study of 150 cases. Hum Pathol 1982; 13:199-209.

9 Weiner JM, Hidayat AA. Juvenile fibrosarcoma of the orbit and eyelid. A study of five cases. Arch Ophthalmol 1983; 101:253-9.

\title{
Chicken pox infection (varicella zoster virus) and acute monoarthritis: Evidence against a direct viral mechanism
}

\author{
C G Fink, S J Read, G Giddins, R P Eglin
}

\section{Department of \\ Virology, Public \\ Health Laboratory, \\ John Radcliffe \\ Hospital, \\ Oxford OX3 9DU \\ C G Fink, S J Read, \\ R P Eglin \\ Department of \\ Orthopaedics, John \\ Radcliffe Hospital \\ G Giddins \\ Correspondence to: \\ Dr C G Fink \\ Accepted for publication \\ 27 August 1991}

\begin{abstract}
A 9 year old boy developed acute monoarthritis of the left knee concurrent with the appearance of a varicella zoster virus (VZV) rash. Repeated VZV DNA hybridisation of the cells within the synovial fluid and synovial membrane failed to show any evidence of intracellular virus. Virus was isolated from synovial fluid 24 hours after the start of clinical infection but not later. These findings suggest that the mechanism of the arthritis is not due to viral replication inside the swollen joint.
\end{abstract}

Acute arthritis is a rare complication of varicella (chicken pox). Sixteen cases have been reported, ${ }^{1}$ and in an earlier review of eight cases five involved one large joint alone. ${ }^{2}$

\section{Case report}

A 9 year old boy presented with a 24 hour history of mild papular-vesicular eruption on the trunk. This eruption developed concurrently over 24 hours with a tender, hot and swollen left knee joint which was sufficiently uncomfortable after 12 hours to inhibit weight bearing. Further crops of vesicles developed over the trunk during the next five days and the knee joint remained acutely inflamed. No vesicles were seen near to the joint. There was no history of previous injury or arthritis and a clinical diagnosis of varicella infection (VZV) was made when the child was admitted for observation and bed rest. The vesicular rash resolved over seven days and the knee joint swelling resolved over three weeks, but complete recovery of the knee joint took two months. 
Six months later the child re-presented with a fever of 24 hours' duration and the same joint acutely swollen. Influenza B virus was isolated from the nasopharynx. The upper respiratory tract infection resolved over seven days and the joint resolved over two weeks.

\section{Pathology}

Twenty four hours after first onset of an acutely swollen knee, the knee was aspirated and a quantity of blood stained fluid withdrawn. This fluid contained monocytes, lymphocytes, red cells and VZV which was isolated by culture on MRC 5 cells. No bacteria were isolated from the knee fluid. The knee joint remained acutely swollen and a more formal exploration took place 52 hours after the onset of the swelling and the skin eruptions.

The synovium was evenly hyperaemic without focal pathology and was biopsied. Further synovial fluid was aspirated and was found to contain monocytes, lymphocytes, and red cells. Virus isolation by tissue culture failed to isolate virus either from the synovial fluid or from a number of ground synovial biopsy specimens. Cells from the two synovial fluid samples (taken at 24 hours and 52 hours) were recovered by centrifugation, and these specimens and the biopsy material from the synovium were fixed in formol saline and prepared as paraffin wax embedded sections. These sections were hybridised with a VZV DNA probe, the Sstg 22 fragment of about 5 kilobases derived from the short unique region of the VZV genome, which is an area coding for early nonstructural proteins $^{3}$ (a kind gift of Dr. Andrew Davison, MRC Institute of Virology, Glasgow). There was no detectable hybridisation of the VZV probe to the fixed cells in three experiments; but a control of VZV infected MRC 5 monolayers, similarly prepared, gave positive results each time. There was no histological evidence of $\mathrm{VZV}$ infection in the cells and tissues recovered from the joint.

\section{Discussion}

Arthritis is a rare complication of primary varicella zoster infection. There is some variation in the temporal observation of the arthritis: in this case it was observed to be concurrent with the first manifestation of the exanthem. There have been reports of monoarthritis on the second ${ }^{4}$ and the third days ${ }^{5}$ of the exanthem. Monoarthritis was recorded in a 2 year old 24 hours before a typical varicella eruption. ${ }^{6}$ It is evident that the arthritis develops in each case within 72 hours of the first skin manifestations of the illness. This period would be within the second viraemic phase of the classically described infection. ${ }^{7}$ Viraemia would account for the large quantity of virus which we isolated from the blood stained synovial fluid removed from the swollen joint within 24 hours of our patient's presentation.

There are two other reports of successful virus isolation from an inflamed joint ${ }^{28}$ although virus isolation has been attempted by seven workers. ${ }^{6}$ The mechanism of development of arthritis in varicella infection is not understood. Direct infection of the joint by varicella virus has been postulated ${ }^{4}$ and this mechanism has been suggested to explain joint inflammation. ${ }^{2}$ If the virus had been replicating within the joint, perhaps as a synovial viral lesion, we would have expected to isolate virus from the joint cellular material at both 24 hours and 52 hours after presentaion. During this time new crops of skin lesions were still appearing. There was widespread cytopathic effect in cell cultures within three days of inoculation with the first synovial fluid, suggesting a large viral load within this specimen. We were unable to isolate any virus from synovial fluid or from synovial biopsy material taken at 52 hours. It is possible that by this time any free virus would have been aggregated by antibody and thus rendered uninfectious for detection by culture. But the virus which is highly cell associated $^{7}$ is protected from antibody and grinding the biopsy material would have released any intracellular virus present into culture. The DNA virus specific probe would have visualised viral DNA within the synovium, or within the free cells of the synovial fluid, and this VZV probe is sensitive down to 50 copies of fragment DNA per cell. ${ }^{9}$ Any intracellular virus present would have given a positive hybridisation result. We found no evidence of intracellular virus.

We believe that the large viral load isolated at 24 hours simply reflects the second viraemic period of the infection. Our evidence does not support viral replication in the joint as a direct focus of inflammation. A more likely mechanism would seem to be a leucocyte mediated inflammation of the joint, engendered during or before the second viraemic phase of the infection. This theory is reinforced by the reappearance of the joint swelling in this patient six months later associated with another viral infection - influenza B. Viraemia is not thought to occur in influenza infection. ${ }^{7} \mathrm{We}$ cannot explain why the arthritis usually affects only one large joint event in VZV infection, ${ }^{4}$ nor can we explain why this same joint, specifically, should inflame again with a further viral infection. A synovial infiltrate of activated inflammatory cells including the monocyte series and $T$ cells that secrete cytokines is suggested for the genesis of rheumatoid arthritis. ${ }^{10} \mathrm{~A}$ similar joint infiltration and inflammation was suggested for a rekindled rheumatoid joint disease seen during treatment with interleukin $2 .{ }^{11}$ This inflammation induced by cytokines may also prove to be the origin of varicella arthritis, and we may be seeing a self limiting model of chronic arthritic disease.

1 De Juan Martin F. Artritis varicelosa en la infancia. Anales Españoles de Pediatria 1986;24:323-4.

2 Priest JR, Urick JJ, Groth KE, Balfour HH. Varicella arthritis documented by isolation of virus from joint fluid. $J$ Paediatr 1978;93:990-2,

3 Davison AJ, Scott JE. Molecular cloning of the varicellazoster virus genome and derivation of six restriction endonuclease maps. J Gen Virol 1983;64:1811-14.

4 Gibson NF, Ogden WS. Varicella arthritis. South Med J 1986;79:1028-30. 
5 Mulhern LW, Friday GA, Perri JA. Arthritis complicating varicella infection. Paediatrics 1971;48:827-9.

6 Fierman AH. Varicella associated arthritis occurring before the exanthem. Clin Paediatr 1990;29:188-90.

7 Heath RB, Kangro HL, Potter CW. Varicella zoster influenza. In: Zuckerman AJ, Banatvala JE, Pattison JR, eds. Principles and practice of clinical virology. London: J Wiley and Sons, 1990:43-68.

8 Evers KG, Zippel C, Kruger J. Varicella arthritis: a rare complication of varicella. Monatsschr Kinderheilkd. 1980;128:147-52.
9 Easton AJ, Eglin RP. In situ hybridisation. In: Sawyer P, ed. Methods in gene technology. 1. London: JAI Press, 1990:185-202.

10 Jira M, Malkovsky M, Denman AM, et al. Lymphokine activated killer cell activity in rheumatoid arthritis. Clin Exp Immunol 1987;68:535-42.

11 Lavelle-Jones M, Al-Hadrani A, Spiers EM, Cambell FC, Cushieri A. Reactivation of rheumatoid arthritis during continuous infusion of interleukin 2. evidence of phocyte control of rheumatoid disease. $B M J 1990 ; 301: 97$.

\title{
Use of serum from patients with polycythaemia or haemochromatosis for laboratory external quality assurance exercises
}

\author{
J I O Craig, P L Yap, C Green, A Stewart, A Ellis, J Seth
}

\begin{abstract}
Some External Quality Assessment Schemes (EQAS) require large volumes of human serum. During a one year period, 595 units of blood were obtained from 87 patients with haemochromatosis and polycythaemia, who underwent therapeutic venesection at the Edinburgh and South East Scotland Blood Transfusion Service. Serum from $59 \%$ of these donations was used in the EQAS for peptide hormones and related substances. The cost of the serum collection was $£ 109 /$ litre, but was only $£ 33 /$ litre of serum if the cost of the actual venesection was excluded. Results from tests on the sera were satisfactory in a variety of immunoassays for several different hormones.
\end{abstract}

EQA schemes with requirements for large volumes of serum should consider therapeutic venesection as a cost effective means of obtaining serum.

In the United Kingdom several External Quality Assessment Schemes (EQAS) have been organised to assess objectively assay results from hospital laboratories, and to evaluate interlaboratory comparability with the aim of improving analytical performance and patient care. ${ }^{1}$ Human serum is required for some schemes and major difficulties are encountered in obtaining the large volumes required.

Repeated venesection of patients who have polycythaemia or haemochromatosis is part of standard management. We therefore investigated the use of serum removed during the venesection of these patients for EQAS.

\section{Methods}

All patients referred for therapeutic venesection to the Blood Transfusion Service from haematology and gastroenterology clinics at the Royal Infirmary of Edinburgh (a 1000 bed hospital) during April 1989 were included in the study. Patients with haemochromatosis underwent venesection weekly until the serum ferritin concentration reached $50 \mu \mathrm{g} / 1$ and thereafter at three to four monthly intervals as required to keep the serum ferritin concentration below this level. Patients with polycythaemia underwent venesection every one to two weeks to a target haemoglobin of $12-13 \mathrm{~g} / \mathrm{dl}$, according to their clinical condition.

Consent was obtained for use of the patient's blood or its components and for routine laboratory testing (including testing for human immunodeficiency virus antibodies and hepatitis B surface antigen). Venesection was performed by trained nursing staff at the Edinburgh and South East Scotland Blood Transfusion Service in an outpatient clinic, the blood being collected into a double blood pack unit without anticoagulants (Fenwall, Travenol Laboratories, Norfolk, England). The blood was then centrifuged and the serum separated, pooled, and stored at $-20^{\circ} \mathrm{C}$ until despatch to the laboratory organising the EQAS for peptide hormones and related substances. On receipt, aliquots were removed for determination of endogenous hormone concentrations and the remainder refrozen after the addition of sodium azide $(0 \cdot 1 \%)$. Pooled sera prepared from donations selected by hormone concentration were passed through a $0.2 \mu \mathrm{m}$ filter and dispersed in nonsterile plastic tubes. Aliquots were then refrozen at $-20^{\circ} \mathrm{C}$, pending distribution at room temperature, to laboratories by first class mail. In some EQAS pools international standards or serum with high concentrations of endogenous hormones were added to give more clinically relevant concentrations, or to assess analytical recovery or specificity.

\section{Results}

A total of 87 patients, 69 with polycythaemia and 18 with haemochromatosis (13 women, 74 men; mean age 60.4 years; range $24-84$ years 